\title{
EVALUATION OF THE NEED TO DISTINGUISH BETWEEN WHITE AND BLACK PATIENTS IN PREDICTING THE COMBINED MESIODISTAL CROWN WIDTH OF CANINES AND PREMOLARS
}

\author{
AVALIAÇÃO DA NECESSIDADE DE DISTINÇÃO ENTRE PACIENTES BRANCOS E NEGROS \\ QUANDO DA ESTIMATIVA DA LARGURA MESIODISTAL COMBINADA DA COROA DE \\ CANINOS E PRÉ-MOLARES
}

Etenildo Dantas CABRAL ${ }^{1}$, Joanna Martins Novais BARBOSA², Ludmila Galindo França de OLIVEIRA ${ }^{3}$

\author{
1- DDS, MSc, PhD, Adjunct Professor, Department of Anatomy, Federal University of Pernambuco. \\ 2- DDS, Graduate student, Department of Anatomy, Federal University of Pernambuco. \\ 3- DDS, Resident at the Interceptive Orthodontics Course of the Hospital for Rehabilitation of Craniofacial Anomalies, University of São Paulo, \\ Bauru, Brazil.
}

Corresponding address: Etenildo Cabral - Federal University of Pernambuco, Department of Anatomy - Cidade Universitária, Recife, Pernambuco, Brazil - Cep.: 50740-530 - Phone: 21268555 - e-mail: etenildo@rce.neoline.com.br

Received: December 13, 2005 - Modification: April 10, 2006 - Accepted: August 08, 2006

\begin{abstract}
$T_{\text {h }}$ combined ( white patients) was selected from the archives of dental clinics in Recife. The mesiodistal crown width of the maxillary and mandibular canines and premolars and of the mandibular incisors was measured in these casts using a caliper with an accuracy of $0.02 \mathrm{~mm}$. The combined mesiodistal crown width of these teeth in the black patients was compared with that found in the white patients, and also with the estimated values obtained by regression equations based on the sample of white patients and on a large sample of a population from the same city. The study demonstrated that there were no significant differences between whites and blacks in the combined mesiodistal crown width of any of the three analyzed teeth groups and also revealed that such equations were statistically accurate in estimating the mesiodistal crown width of canines and premolars in blacks. It was concluded that there is no need for specific tables or equations regarding the patient's race in the analysis of mixed dentition in Recife.
\end{abstract}

Uniterms: Dentition, mixed; Orthodontics, interceptive; Blacks.

\begin{abstract}
RESUMO
objetivo do presente estudo foi avaliar a necessidade de distinção entre pacientes brancos e negros quando da estimativa da largura mesiodistal combinada da coroa de caninos e pré-molares em Recife. Uma amostra de 120 modelos de gesso (60 de negros e 60 de brancos) foi selecionada dos arquivos de clínicas do Recife. As larguras mesiodistais das coroas dos caninos e pré-molares superiores e inferiores e dos incisivos inferiores foram medidas nesses modelos, utilizando-se um paquímetro com precisão de $0,02 \mathrm{~mm}$. As larguras mesiodistais combinadas desses dentes nos pacientes negros foram comparadas com aquelas encontradas nos pacientes brancos; e comparadas com aquelas estimadas por equações de regressão elaboradas com base na amostra de pacientes brancos e com base em uma ampla amostra de recifenses. $\mathrm{O}$ estudo verificou não apenas a não diferença significativa entre brancos e negros na largura mesiodistal combinada de nenhum dos três grupos de dentes analisados, como também verificou que equações elaboradas com base na amostra de indivíduos brancos ou na amostra de recifenses foram estatisticamente precisas em estimar a largura de caninos e pré-molares dos negros. O estudo concluiu que não há necessidade de tabelas ou equações específicas segundo a raça do paciente para a análise de dentição mista em Recife. Unitermos: Dentição mista; Ortodontia interceptora; Negros.
\end{abstract}




\section{INTRODUCTION}

The period of mixed dentition is a very important topic in general dentistry, especially in orthodontics. The dentoalveolar changes that take place in this period determine patient's occlusion and esthetics. The amount and pace of these changes draw parents' attention, motivating them to seek professional advice on whether or not their children need orthodontic treatment.

In the professional assessment, analysis of the amount of space available for the accommodation of permanent teeth is a very important step for an appropriate orthodontic diagnosis and treatment planning. Various methods for this analysis have been proposed in order to estimate the mesiodistal crown width of unerupted canines and premolars, such as radiographic ${ }^{16}$, statistical ${ }^{14}$, combination of radiographic and statistical methods ${ }^{19,20}$ and just the simple visual observation ${ }^{21}$. The statistical methods based on the combined mesiodistal crown width of the lower incisors are the most commonly used ${ }^{13}$.

However, given that dental morphology is strongly correlated to individual's ethnic origin ${ }^{1}$, probability equations and tables developed from studies in a certain population may not be accurate when applied to a different population ${ }^{11}$. Therefore, the widely used Moyers' tables ${ }^{13}$, which were based on a North American population, were not accurate for Brazilians ${ }^{3-5}$.

Racial specificity has also been studied and differences have been found in the crown width of canines and premolars among white and black individuals in several countries ${ }^{12,17}$, and specific equations or tables have been created for blacks ${ }^{7,18}$. Nevertheless, the effect of the patient's race in estimating the mesiodistal crown width of unerupted teeth has still not been analyzed in Brazil. The aim of the present study is thus to evaluate the need to distinguish between white and black patients in predicting the combined mesiodistal crown width of canines and premolars in Recife, Brazil.

\section{MATERIAL AND METHODS}

\section{Sample}

A sample of 120 dental casts, 60 from black and 60 from white patients (30 male and 30 female for each race) was selected from the archives of orthodontic clinics in Recife (Post-graduation Orthodontic Clinic of Pernambuco Federal University, Dental Clinic of the General Hospital of Recife, Clinic of the Orthodontic Study Group of Recife, and Dental Clinic of the Military Police of Pernambuco). Casts were selected randomly, although they had to fulfill the following requirements:

a) Permanent dentition with complete eruption of teeth to be measured, to allow the correct positioning of the measuring instrument;

b) No severe crowding, in order not to encounter difficulties in measuring the mesiodistal crown width of the teeth (regardless of the type of the occlusion); c) No evidence of caries, fracture or proximal restorations in teeth to be measured, which could alter the mesiodistal tooth width;

d) Patients up to 18 years of age, with no history of previous orthodontic treatment, to avoid significant wear or interproximal stripping of the teeth to be measured (patients' age varied from 13 to 18 years; mean: 15 years for both race groups);

e) Patients with clinical records informing their race, to allow categorization of the cast according to the patient's race.

\section{Racial Categorization}

In Brazil, the use of the variable race from a biological standpoint may be controversial, especially when considering genetic foundations ${ }^{15}$. However, its use is completely justified from a social standpoint ${ }^{6}$. The present study therefore categorized the casts according to the patient's race considering the race written by the professional in the patient's clinical record. Such a racial categorization was probably determined by patient's phenotypical characteristics. Brazilians usually use this criterion to define one's race, mainly by their skin colour? This is also how the professional would proceed, in case he/she had to choose a specific method to estimate the mesiodistal crown width of canines and premolars in regard to patient's race. Therefore, the racial categorization used in the present study would be similar to that used in daily clinical practice.

\section{Measurement}

The mesiodistal crown widths of the maxillary and mandibular canines and premolars, as well as of the mandibular incisors were measured from the selected casts. In normal aligned teeth, the maximum distance between the contact points on the approximal surfaces was the width considered. Otherwise, the distance between the approximal contacts that would occur if teeth were aligned was measured. A caliper with an accuracy of $0.02 \mathrm{~mm}$ (Western) was used for taking the measurements, which was held parallel to occlusal surface and perpendicular to buccal surface of the tooth crown. The same operator performed all measurements and was previously calibrated for this (tests of measurement reliability showed highly significant values).

\section{STATISTICAL ANALYSIS}

The paired t-test was used for analyzing whether there was difference between the antimeres, in regard to the combined mesiodistal crown width of canines and premolars. No significant differences ( $p>0.05$ ) were observed; therefore the other analyses were based on the mean value between the right and left sides.

The combined mesiodistal crown width of canines and premolars, and the combined mesiodistal crown width of the mandibular incisors in the black patients were compared with those found in the white patients. A non- 
paired t-test was used for this.

Simple regression equations for estimating the combined mesiodistal crown width of canines and premolars from the combined mesiodistal crown width of the mandibular incisors were created for the white patients. Afterwards, the combined mesiodistal crown widths of canine and premolars found in the black patients were compared with those estimated by the simple regression equations elaborated for the sample of white patients.

Finally, the combined mesiodistal crown widths of canine and premolars found for the black patients were compared with those estimated by simple regression equations elaborated in a previous study based on a large sample of a population from Recife ${ }^{4}$. These equations were: $\mathrm{Y}=12.2+0.44 \mathrm{X}$ for maxillary arch in males; $\mathrm{Y}=9.9+0.51 \mathrm{X}$ for mandibular arch in males; $Y=10+0.51 X$ for maxillary arch in females; $Y=8.1+0.56 X$ for mandibular arch in females.

\section{RESULTS}

The combined mesiodistal crown widths of mandibular incisors, maxillary canines and premolars, and mandibular canines and premolars found in the black patients were not statistically different to those found in the white patients ( $p>0.05)$. This occurred with both genders (Table 1).

The combined mesiodistal crown widths of maxillary canines and premolars and mandibular canines and premolars found in the black patients' sample were not statistically different to those estimated for this group of teeth through:

a) Regression equations derived from the white patients' sample of this study ( $\mathrm{p}=0.85$ and 0.98 for males, and 0.83 and 0.43 for females, for the maxillary and mandibular arch, respectively);

b) Equations derived from a sample of a population from Recife in a previous study ( $\mathrm{p}=0.50$ and 0.63 for males, and 0.18 and 0.06 for females, for the maxillary and mandibular arch respectively).
The regression lines in Figure 1 clearly show, by its close slope and intercept, the similarity between black and white patients in the relationship between the combined mesiodistal crown width of mandibular incisors and of canines and premolars.

\section{DISCUSSION}

Unlike the reality of a decade ago, economically deprived populations have now an easier access to orthodontic treatment in Brazil. Thus the access to this specialty has considerably increased among the black population, which is socioeconomic disadvantaged in this country ${ }^{10}$. Therefore, orthodontic studies for this race are needed. The present study, despite the limitation of not having a national wide sample, offers a first and important reference in regard to the variable race in the analysis of mixed dentition in Brazil.

It is important to mention that the present study was

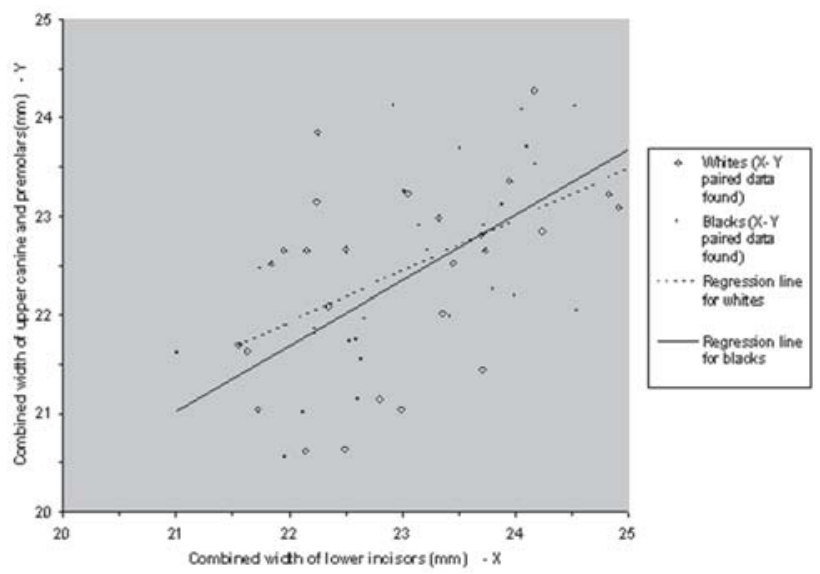

FIGURE 1- Dispersion diagram with regression line of combined mesiodistal crown width of mandibular incisors versus the maxillary canines and premolars in males, according to the patient's race

TABLE 1- Combined mesiodistal crown width of mandibular incisors and of canines and premolars according to patient's gender and race, in millimeters

\begin{tabular}{|c|c|c|c|c|c|c|}
\hline \multirow[t]{3}{*}{ Group of teeth } & \multirow[t]{3}{*}{ Gender } & \multicolumn{4}{|c|}{ Patient's race } & \multirow{3}{*}{$\begin{array}{l}p \text { value } \\
\text { (t-test) }\end{array}$} \\
\hline & & \multicolumn{2}{|c|}{ Black } & \multicolumn{2}{|c|}{ White } & \\
\hline & & mean & $\mathbf{s d}^{*}$ & mean & $\mathbf{s d}^{*}$ & \\
\hline \multirow[t]{2}{*}{ Mandibular incisors } & Male & 23.40 & 1.15 & 23.31 & 1.29 & 0.78 \\
\hline & Female & 23.13 & 1.25 & 23.11 & 1.39 & 0.95 \\
\hline \multirow[t]{2}{*}{ Maxillary canines and premolars } & Male & 22,62 & 1.20 & 22.60 & 1.08 & 0.96 \\
\hline & Female & 22.01 & 1.12 & 21.97 & 0.95 & 0.88 \\
\hline \multirow[t]{2}{*}{ Mandibular canines and premolars } & Male & 21.93 & 1.44 & 21.90 & 1.03 & 0.92 \\
\hline & Female & 21.41 & 1.04 & 21.28 & 0.79 & 0.61 \\
\hline
\end{tabular}

* standard deviation 
aware of the fact that even when the combined mesiodistal crown widths of incisors and of canines and premolars were on average different when comparing two populations, the relationship between these widths may be the same in these populations. Hence, the equation elaborated for predicting the combined mesiodistal crown width of canines and premolars from the incisors' mesiodistal crown width, based on a certain population, may also be accurate for another population, even if these populations have different mean values. The present study therefore has not merely analyzed the mean values of the combined mesiodistal crown widths of incisors and of canines and premolars according to the patient's race, but also verified whether the regression equations elaborated from a sample of white patients and from a previous study in Recife were precise for black patients. As result, it has demonstrated that there were no significant differences between whites and blacks in the combined mesiodistal crown width of any of the three teeth groups analyzed and also revealed that such equations were statistically accurate in estimating the mesiodistal crown width of canines and premolars in black people.

These results, therefore, showed that there is no need for any specific tables or equations regarding the patient's race in the analysis of mixed dentition in Recife. In Brazil, further studies are needed to confirm these findings, although studies analyzing the mixed dentition in different Brazilian states have found similar results ${ }^{3-5}$.

The results of the present study were not expected, because almost the entire scientific literature showed larger mesiodistal tooth width in black people $\mathrm{e}^{12,17}$, and suggested the need of specific tables or equations for this race $^{7,18}$. Only Frankel and Benz ${ }^{8}$ reported that there were no significant differences in the regression equations elaborated for the maxillary arch in blacks, in comparison to published equations for white subjects, even though there were differences in regard to the mandibular arch. However, the study mentioned showed a limitation, since the equations for white people did not distinguish the gender.

Perhaps the results found in this study may be explained by the miscegenation that took place in Brazil, where individuals categorized as whites have a larger frequency of genetic markers of African origin than of European origin ${ }^{15}$. This miscegenation determined no significant difference in the combined mesiodistal crown width of incisors, canines and premolars between "white" and "black" Brazilians. This hypothesis might be reinforced by the fact that combined mesiodistal crown widths of canines and premolars in Brazilian samples are larger than those reported in American whites $^{3-5}$. In other words, the larger mesiodistal crown width in "pure" black individuals may be an important factor in the average increase of the mesiodistal crown width of this teeth group in Brazilians.

One could presume that the present study results are due to the higher heterogeneity in terms of race of the population from Recife than from other Brazilian capitals such as Salvador (highest proportion of black people) and Porto Alegre (the smallest proportion). Following the same reasoning, in these latter two cities there could be significant differences in crown widths of teeth so there would be the need of distinction between white and black patients in predicting the combined mesiodistal crown width of canines and premolars. Investigations in other Brazilian capitals are therefore needed.

However, it is important to highlight that other studies from different regions in Brazil have obtained similar results regarding the analysis of mixed dentition ${ }^{3-5}$ and that the miscegenation in Brazil is simply beyond persons' skin color: ${ }^{15}$ thus, studies in these other capitals would probably achieve the same results as the present study. In addition, such studies should be carried out in order to compare white and black patients from the same city or state. For instance, comparing the black population from Salvador to the white population from Porto Alegre would not be clinically relevant, as hardly a dentist would have patients from both cities. Hence, a method to distinguish black patients from Salvador and white patients from Porto Alegre would be inadequate.

Another important aspect in the present study is that the selected cases for the black patients group were those classified exactly as "black" by the dentists. Those patients classified as "dark-skinned", "mulatto" or "brunet” were not included in the black category, as it is seen in many studies of social charater ${ }^{10}$. These patients were in fact excluded. The purpose of this procedure was to make the groups more heterogeneous. Nevertheless, there were no significant differences between white and black patients. Based on this fact, it would be irrelevant to compare the various nuances of color/race present in Brazil with regard to predicting the mesiodistal crown width of canines and premolars.

On the other hand, the attempt to establish a more precise way of racial categorization for the formation of white and black patients' groups and latter comparison, such as Frankel and Benz ${ }^{8}$ accomplished in their study considering the patients' ancestries, would be a procedure of little practical relevance as hardly the dentists would do the same in daily clinical practice. In other words, there is no purpose in establishing a method for categorization if it will not be used by professionals. For that reason, the present study used dentists' own categorization. It is worth mentioning that it was exactly in Frankel and Benz's study ${ }^{8}$ that no difference was found between black and white persons regarding the use of regression equations to estimate the combined crown width of maxillary canines and premolars.

The method in which the sample was selected and categorized in this study was a limiting factor for its statistical representativeness regarding the population from Recife. This occurred place since few cases that dentists categorized as black were found, although the clinics whose archives were examined care for a less privileged population. For that reason, over five hundred dental records were examined in order to achieve the minimum sample of sixty black patients. A new study with an active search of black individuals would be interesting to obtain a wider sample and to confirm or not to confirm the present study's data.

It is also important to state that the present study did not verify the need to distinguish a black from a white patient 
merely regarding the prediction of the combined mesiodistal crown width of canines and premolars. Other inherent aspects to the orthodontic treatment need to be investigated in the focus of racial matter. Racial variation has been pointed out in different aspects of orthodontic treatment ${ }^{2}$, even though no finding has been made in Brazil.

\section{CONCLUSION}

It was concluded that there is no need for specific tables or equations regarding the patient's race in the analysis of mixed dentition in Recife. In Brazil, as a whole, further studies are needed to confirm these findings.

\section{REFERENCES}

1- Bishara SE, Jakobsen JR, Abdallah EM, Garcia AF. Comparisons of mesiodistal and buccolingual crown dimensions of the permanent teeth in three populations from Egypt, Mexico, and the United States. Am J Orthod Dentofacial Orthop. 1989;96:416-22.

2- Brock RA 2nd, Taylor RW, Buschang PH, Behrents RG. Ethnic differences in upper lip response to incisor retraction. Am J Orthod Dentofacial Orthop. 2005;127:683-91.

3- Cabral ED, Caldas Jr AF, Cabral Filho H, Caldas SGFR. Avaliação das tabelas de Moyers para estimar a largura de canino e pré-molares - um estudo em Natal-RN. J Bras Ortodon Ortop Facial. 2004;9:3740

4- Cabral ED, Moraes SRA. Avaliação do emprego das tabelas de Moyers para análise de dentição mista, em pacientes da cidade do Recife. Rev Cons Reg Odontol Pernambuco. 2000;3:33-8.

5- Cabral ED, Pessôa AG. Análise de dentição mista - avaliação das tabelas de Moyers em Campina Grande, Paraíba. J Bras Ortodon Ortop Facial. 2002;7:235-7.

6- Costa S. A construção sociológica da raça no Brasil. Estudos AfroAsiáticos. 2002;24:35-61.

7- Ferguson FS, Macko DJ, Sonnenberg EM, Shakun ML. The use of regression constants in estimating tooth size in a Negro population. Am J Orthod. 1978;73:68-72.

8- Frankel HH, Benz EM. Mixed dentition for black Americans Pediatr Dent. 1986;8:226-30.

9- Heringer R. Desigualdades raciais no Brasil: síntese de indicadores e desafios no campo das políticas públicas. Cad Saúde Pública. 2002;18:57-65.

10- Jaccoud L, Beghin N. Desigualdades raciais no Brasil: um balanço da intervenção governamental. Brasília: Ipea; 2002.

11- Jaroontham J, Godfrey K. Mixed dentition space analysis in a Thai Population. Eur J Orthod. 2000;22:127-34.

12- Merz ML, Issacson RJ, Germane N, Rubenstein LK. Tooth diameters and arch perimeters in a black and a white population. Am J Orthod Dentofacial Orthop. 1991;100:53-8.

13- Moyers RE. Ortodontia. 4th ed. Rio de Janeiro: Guanabara Koogan; 1991.
14- Nourallah AW, Gesch D, Khordaji MN, Splieth C. New regression equations for predicting the size of unerupted canines and premolars in a contemporary population. Angle Orthodontist. 2002;72:21621

15- Parra FC, Amado RC, Lambertucci JR, Rocha J, Antunes CM, Pena SDJ. "Color and genomic ancestry in Brazilians". Proceedings of the National Academy of Sciences USA 2003;100:177-82.

16- Ruellas ACO. Radiografia com tela milimetrada: método alternativo para cálculo do espaço requerido na análise de dentição mista. Rev Dent Press Ortodon Ortoped Facial 2001;6:77-80.

17- Schirmer UR, Malan JA, Viljoen E. Comparison of mesiodistal crown dimensions of South African blacks and whites. J Dent Res. 1995;74:1020.

18- Schirmer UR, Wiltshire WA. Orthodontic probability tables for black patients of Africa descent: mixed dentition analysis. Am J Orthod Dentofacial Orthop. 1997;112:545-51.

19- Staley RN, Kerber PE. A revision of the Hixon and Oldfather mixed-dentition prediction method. Am J Orthod. 1980;78:296-302.

20- Staley RN, O’gorman TW, Hoag JF, Shelly TH. Prediction of the width of unerupted canines and premolars. JADA. 1984;108:185-90.

21- Tootla R, Fayle SA. Comparison of two methods of space prediction in the mixed dentition. Pediatr Dent. 2003;25:350-6. 